\title{
Effects of mycoprotein on glycaemic control and energy intake in humans: a systematic review
}

\author{
Anna Cherta-Murillo ${ }^{1 *}$, Aaron M. Lett ${ }^{1}$, James Frampton ${ }^{1}$, Edward S. Chambers ${ }^{1}$, Tim J. A. Finnigan ${ }^{2}$ and \\ Gary S. Frost ${ }^{1}$ \\ ${ }^{1}$ Section for Nutrition Research, Department of Metabolism, Digestion and Reproduction, Faculty of Medicine, Imperial College \\ London, Hammersmith Hospital, London W12 ONN, UK \\ ${ }^{2}$ Marlow Foods Ltd, Stokesley, Yorkshire, UK \\ (Submitted 23 October 2019 - Final revision received 3 February 2020 - Accepted 11 February 2020 - First published online 26 February 2020)
}

\section{Abstract}

Mycoprotein is a food high in both dietary fibre and non-animal-derived protein. Global mycoprotein consumption is increasing, although its effect on human health has not yet been systematically reviewed. This study aims to systematically review the effects of mycoprotein on glycaemic control and energy intake in humans. A literature search of randomised controlled trials was performed in PubMed, Embase, Web of Science, Google Scholar and hand search. A total of twenty-one studies were identified of which only five studies, totalling 122 participants, met the inclusion criteria. All five studies were acute studies of which one reported outcomes on glycaemia and insulinaemia, two reported on energy intake and two reported on all of these outcomes. Data were extracted, and risk-of-bias assessment was then conducted. The results did not show a clear effect of acute mycoprotein on blood glucose levels, but it showed a decrease in insulin levels. Acute mycoprotein intake also showed to decrease energy intake at an ad libitum meal and post- $24 \mathrm{~h}$ in healthy lean, overweight and obese humans. In conclusion, the acute ingestion of mycoprotein reduces energy intake and insulinaemia, whereas its impact on glycaemia is currently unclear. However, evidence comes from a very limited number of heterogeneous studies. Further well-controlled studies are needed to elucidate the short- and long-term effects of mycoprotein intake on glycaemic control and energy intake, as well as the mechanisms underpinning these effects.

Key words: Mycoprotein: Glycaemic control: Energy intake: Systematic reviews

Non-communicable diseases are responsible for $71 \%$ of annual global deaths ${ }^{(1)}$. The most important risk factors for non-communicable diseases are elevated blood glucose (hyperglycaemia) and excessive body weight ${ }^{(2)}$. Postprandial hyperglycaemia is defined as blood glucose levels $\geq 7 \cdot 8 \mathrm{mmol} / 1$ (considered as impaired glucose tolerance) or $\geq 11.1 \mathrm{mmol} / 1$ (considered as diabetes) $180 \mathrm{~min}$ after the consumption of a $75 \mathrm{~g}$ glucose load ${ }^{(3)}$. Excessive body weight results from an imbalance between energy intake and energy expenditure, and it is diagnosed using BMI of which values $\geq 25-29.9$ or $\geq 30 \mathrm{~kg} / \mathrm{m}^{2}$ are categorised as 'overweight' or 'obese', respectively ${ }^{(4)}$. The aetiology of hyperglycaemia and increased body weight is multi-factorial, with lifestyle (e.g. diet and exercise) being a significant contributing factor to both $^{(5)}$.

Dietary interventions are therefore employed as a cornerstone strategy for the prevention and management of both hyperglycaemia and increased body weight ${ }^{(6)}$. Of relevance, dietary fibre has been shown to positively modulate both blood glucose levels and energy homoeostasis via a myriad of mechanisms. For example, soluble fibres can delay gastric emptying, glucose absorption in the small intestine and starch degradation; all of which contribute to decreasing blood glucose levels. Also, soluble fibres have been shown to stimulate the secretion of hormones such as glucagon-like peptide 1 (GLP-1) which acts as an incretin (stimulating the secretion of insulin) and promotes pancreatic $\beta$-cell growth ${ }^{(7)}$. In contrast, insoluble fibres interact with host digestive enzymes to attenuate digestible polysaccharide hydrolysis and consequently dampen the glycaemic response $^{(8)}$. Furthermore, insoluble fibres can be fermented by the gut microbiota to produce bioactive metabolites - such as the SCFA acetate, butyrate and propionate ${ }^{(9)}$ - which can stimulate incretin effects in the peripheral circulation ${ }^{(10)}$.

With regard to energy homoeostasis, dietary fibre has been shown to reduce energy intake via various mechanisms ${ }^{(11)}$. Increased bulk and viscosity ${ }^{(12)}$, increased gastric distension ${ }^{(13)}$ and decreased gastric emptying ${ }^{(14)}$ have all been implicated in fibre-induced satiety. Additionally, the release of the anorexigenic

Abbreviations: GLP-1, glucagon-like peptide 1; PYY, peptide tyrosine tyrosine; RCT, randomised controlled trial

* Corresponding author: Anna Cherta-Murillo, email anna.cherta-murillo17@imperial.ac.uk 
hormones GLP-1 and peptide tyrosine tyrosine (PYY) following fibre ingestion (due to mechanisms such as gut-derived SCFA production $^{(15)}$ ) may also be a key driver of this effect. Overall, these processes result in a decrease in appetite and energy intake which can ultimately facilitate body weight loss.

Dietary protein has also been shown to positively influence blood glucose levels ${ }^{(16)}$ through mechanisms that are not yet fully defined. Putative mechanisms include the effects of incretin secretion (e.g. GLP-1 and gastric inhibitory peptide ${ }^{(17)}$ ), as well as the insulin secretagogue effects of amino acids ${ }^{(18)}$. Moreover, dietary protein can increase satiety and suppress energy intake, possibly via its effect on gluconeogenesis ${ }^{(19)}$, diet-induced thermogenesis $^{(20)}$ and/or release of anorexigenic hormones from the gastrointestinal tract ${ }^{(21)}$. Therefore, foods high in both dietary fibre and protein may modulate blood glucose levels, appetite and consequently energy intake to a greater extent than foods that contain either fibre or protein alone.

Mycoprotein is the name given to the biomass of fungal filaments produced following the continuous fermentation of a glucose substrate by the microscopic fungus Fusarium venenatum $^{(22)}$. Owing to its fungal nature, mycoprotein is high in both dietary fibre $(6 \mathrm{~g} / 100 \mathrm{~g}$ wet weight; composed of $1 / 3$ chitin and $2 / 3 \quad \beta$-glucan) and non-animal-derived protein (11 g/100 g wet weight) (Table 1; Fig. 1). Mycoprotein constitutes an ingredient which is processed into foods that resemble animalderived meat products (e.g. nuggets, mince, fish fingers) and sold under the brand name of Quorn ${ }^{\mathrm{TM}}$. Quorn ${ }^{\mathrm{TM}}$ foods have similar organoleptic properties to meat (taste and appearance)

\begin{tabular}{lc}
$\begin{array}{l}\text { Table 1. Macronutrient } \\
\text { mycoprotein (wet weight) }\end{array}$ & composition of $100 \mathrm{~g}$ of \\
\hline & $\begin{array}{c}\text { Amount per } 100 \mathrm{~g} \text { as } \\
\text { wet weight (as consumed) }\end{array}$ \\
\hline Energy (kJ) & 356 \\
Carbohydrates $(\mathrm{g})$ & 9 \\
Sugars $(\mathrm{g})$ & 0 \\
Fat $(\mathrm{g})$ & 3 \\
$\quad$ Of which saturates $(\mathrm{g})$ & $0 \cdot 7$ \\
Protein $(\mathrm{g})$ & 11 \\
Fibre $(\mathrm{g})$ & 6 \\
\hline
\end{tabular}

(a)

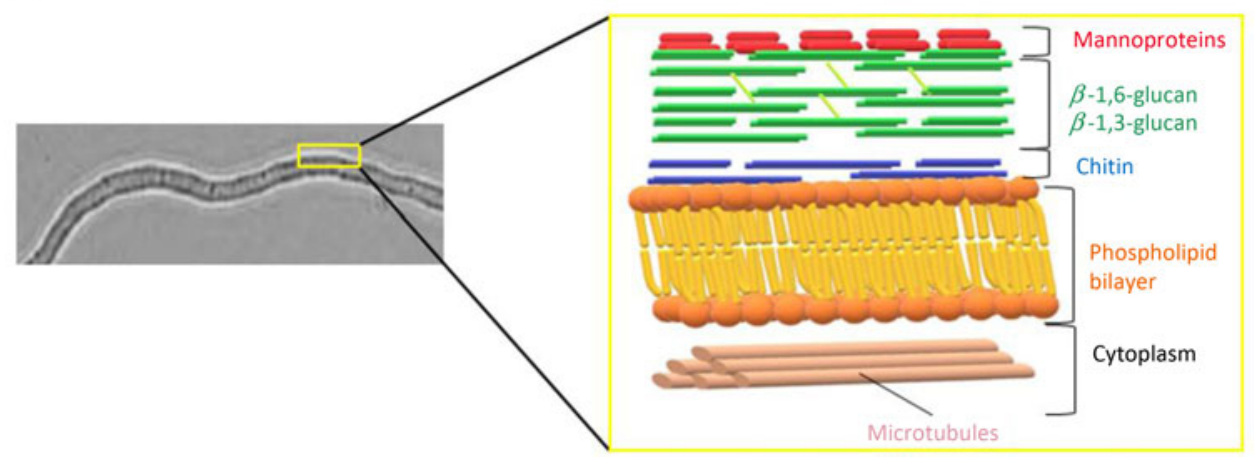

Protein $(g)$

(b) and contain all nine essential amino acids, making it a popular meat substitute.

Mycoprotein is commercially available in the USA, Europe, Asia and Australia and becoming increasingly incorporated into the diet of many populations ${ }^{(22)}$. Mycoprotein is, therefore, a significant source of dietary fibre and non-animal-derived protein for numerous consumers worldwide. As such, and as mycoprotein consumption continues to increase, it is of growing interest to understand its role in nutrition and health. Randomised controlled trials (RCT) have been conducted to investigate the effects of mycoprotein on blood glucose and energy intake in healthy humans. However, to the best of our knowledge, such work has not been systematically reviewed, appraised and synthesised to provide a consensus on the role of mycoprotein in glycaemic control and energy intake regulation. In this paper, we aim to systematically review the RCT investigating the effects of mycoprotein on glycaemic control and energy intake in humans.

\section{Methods}

A systematic review of peer-reviewed literature published up to the 3 November 2019 was performed. The systematic review was conducted, in adherence to the Preferred Reporting Items for Systematic Reviews and Meta-analysis (PRISMA) guidelines ${ }^{(26)}$. The protocol for this review has been registered in PROSPERO 2018 (CRD42018114566) (online Supplementary Table S1) and is available from https://www.crd.york.ac.uk/ PROSPERO/display_record.php?RecordID $=114566$.

\section{Eligibility criteria}

The PICOS (patients, intervention, comparator, outcome, study design) criteria were used to establish study eligibility and focus the research question (Table 2).

\section{Search strategy}

The conducted search strategy was performed within the PubMed, Embase, Web of Science and Google Scholar database. The search used a combination of terms of both title headings, keywords or free-text words detailed in online Supplementary

Table S2, with the English language and a date cut-off of

Fig. 1. (a) Fungal filament of Fusarium venenatum and (b) simplified schematic representation of the fungal cell wall (constituted by mannoproteins - constituting the protein source, $\beta$-1,6-glucan, $\beta$-1,3-glucans and chitin - constituting the fibre sources), phospholipid bilayer and cytoplasm including microtubules ${ }^{(23)}$ - protein source. Figure adapted from Wiebe and Fesel \& Zuccaro(24,25). 
Table 2. PICOS (patients, intervention, comparator, outcome, study design) criteria for inclusion and exclusion of studies

\begin{tabular}{|c|c|c|}
\hline Criteria & Inclusion & Exclusion \\
\hline Participants & Humans & Animals \\
\hline Intervention & Studies assessing mycoprotein intake in any form & No mycoprotein or mycoprotein mixed with other sources of fibre \\
\hline Comparator & & No comparators were excluded \\
\hline Outcome & $\begin{array}{l}\text { Studies that contain a quantifiable measure of glucose, insulin } \\
\text { appetite and/or energy intake }\end{array}$ & $\begin{array}{l}\text { Studies that do not contain a quantifiable measure of the } \\
\text { outcomes of interest }\end{array}$ \\
\hline Study design & $\begin{array}{l}\text { Study designs which generate empirical data from randomised } \\
\text { controlled trial. Only results analysed statistically will be included }\end{array}$ & $\begin{array}{l}\text { Reviews, conference abstracts, dissertation abstracts, lectures, } \\
\text { information pieces and corrigendums were not included } \\
\text { Studies were limited to English language up to } 3 \text { November } 2019\end{array}$ \\
\hline
\end{tabular}

3 November 2019. The following PubMed search algorithm was used: (mycoprotein[All Fields] OR myco-protein[All Fields] OR fungi-derived protein[All Fields] OR quorn[All Fields]) AND (glucose[MeSH Terms] OR A1c[All Fields] OR glycatedhaemoglobin[All Fields] OR hba1c [All Fields] OR haemoglobin a [All Fields] OR dysglycemia [All Fields] OR dysglycaemia [All Fields] OR glycaemia[All Fields] OR glycemia [All Fields] OR glycaemic[All Fields] OR glycemic[All Fields] OR insulin*[All Fields] OR insulin [All Fields] OR fasting [All Fields] OR postprandial [All Fields] OR homeostatic model assessment [All Fields] OR oral glucose tolerance test [All Fields] OR oral glucose tolerance test [All Fields] OR appetite [All Fields] OR energy intake [All Fields] OR food intake [All Fields] OR food behaviour [All Fields] OR food behavior [All Fields] OR eating behaviour [All Fields] OR eating behavior [All Fields] OR hunger [All Fields] OR food consumption [All Fields]).

Also, manual searches of bibliographies of original research and previous reviews were performed, to identify additional relevant articles.

\section{Study selection}

All articles identified by the search strategy were reviewed by two reviewers independently (A. C.-M. and A. M. L.). Title and abstract of each group of articles were screened by A. C.-M. and A. M. L. Post-screening, full-text articles indicated as potentially relevant were retrieved and study eligibility was assessed. Study eligibility was conducted, through assessing the title, abstract and full text against the defined inclusion and exclusion criteria (see Table 2). For both screening and assessment of study eligibility, all unclear eligibility of papers was resolved by consulting a third party (E. S. C.). Identified duplicates were removed.

\section{Data extraction and management}

Articles deemed eligible for inclusion were assigned to subject categories, reflective of the two outcomes of interest (glycaemic control and energy intake), dependent on the outcome of the article reported. Articles could be assigned to more than one subject category if they reported outcomes relevant to two of the subject categories. Tabulated summaries were derived from the extracted data of articles assigned to the subject category (Tables 3 and 4). The tabulated summary for studies assessing mycoprotein intake on glycaemic control, energy intake and appetite contained the following descriptors:
- Reference - presents the bibliographic reference of the study.

- Participants - presents the characteristics of the population (sample size ( $n$ ), sex, age, BMI, healthy and smoker status).

- Study information - presents the study design (randomised, controlled, blinded, crossover), the test food (form, quantity of mycoprotein, control type and amount of carbohydrate given with the meal) and the protocol of the study.

- Outcome - presents the result of the outcome of interest in the study. For energy intake and appetite, the methods of assessment are described in each.

\section{Risk-of-bias assessment}

Studies were assessed for risk of bias by two independent reviewers (A. C. M. and A. M. L.) following the Cochrane Risk of Bias Assessment Tool. The five methodological features assessed were selection, performance, detection, attrition and reporting bias. Studies were classified as 'high risk' if they contained methodological flaws that may have influenced the results, 'low risk' if the flaw was not deemed to have affected the results and 'unclear risk' if not enough information was provided to perform a judgement. Disagreements in the classification were resolved by consulting a third party (E. S. C.).

\section{Data analysis}

Demographic data and described outcome values were reported as mean values and standard deviations.

Glycaemic control was defined as blood glucose and insulin AUC or incremental AUC. In addition, for one study ${ }^{(29)}$, mean glucose levels $(\mathrm{mmol} / \mathrm{l})$ were reported at fasting $(0 \mathrm{~h})$, early $(0-2 \mathrm{~h})$ and late $(2-4 \mathrm{~h})$ postprandial stages. Energy intake was defined as acute energy intake ( $\leq 5 \mathrm{~h}$ post-ingestion) which included ad libitum meal and as short-term energy intake ( $>5 \mathrm{~h}$ post-ingestion) which included food diaries. Energy intake at $\mathrm{ad}$ libitum was assessed via buffet meal, macronutrient selfselection paradigm and universal eating monitor, and energy intake post-visit was assessed using self-reported food diaries. Appetite was measured via subjective appetite feelings scoring $(\mathrm{mm})$ using a visual analogue scale. When possible, all outcomes were calculated as the percentage of change compared with control.

A statistical meta-analysis of the results was not possible due to the heterogeneity in the reported glycaemic outcomes and the insufficient power of studies assessing the energy intake outcomes measurement. Therefore, for all outcomes, a systematic, narrative approach was conducted according to the Cochrane 


\section{NS British Journal of Nutrition}

Table 3. Summary of the acute randomised trials on glycaemic control

(Numbers and percentages; mean values and standard deviations)

\begin{tabular}{|c|c|c|c|c|c|c|c|}
\hline \multirow[b]{2}{*}{ References } & \multicolumn{3}{|r|}{ Participants } & \multicolumn{3}{|c|}{ Study information } & Outcome \\
\hline & $n$ & $\begin{array}{l}\text { Male/ } \\
\text { female }\end{array}$ & $\begin{array}{l}\text { Characteristics (age/BMl/ } \\
\text { health/smoking status) }\end{array}$ & Study design & $\begin{array}{l}\text { Test food (form/quantity of mycoprotein/ } \\
\text { control type/CHO) }\end{array}$ & Protocol & Glycaemic and insulinaemic response \\
\hline (27) & 19 & $4 / 15$ & $\begin{array}{l}\text { Mean: } 22.8 \text { (sD 3.55) years/ } \\
\text { mean: } 22.74 \text { (sD 2.59) } \\
\mathrm{kg} / \mathrm{m}^{2} / \text { healthy } / \text { not reported }\end{array}$ & $\begin{array}{l}\text { RCT, single- } \\
\text { blinded, } \\
\text { crossover }\end{array}$ & $\begin{array}{l}\text { Drink/20 g dry weight/energy and } \\
\text { macronutrient-matched (except fibre) } \\
\text { soya-based protein drink } / 75 \mathrm{~g} \mathrm{CHO}\end{array}$ & $\begin{array}{l}\text { Participant fasted overnight. Blood } \\
\text { sampling at fasting, } 30,60,120 \mathrm{~min} \\
\text { relative to test food }\end{array}$ & $\begin{array}{l}\text { Glucose } \mathrm{AUC}_{0-60 \mathrm{~min}}: 9 \% \text { decrease with } \\
\text { mycoprotein }(P<0.03) \\
\text { Glucose } \mathrm{AUC}_{0-120 \mathrm{~min}}: \mathrm{NSSD} \\
\text { Insulin } \mathrm{AUC}_{0-60 \mathrm{~min}}: 20 \% \text { decrease with } \\
\text { mycoprotein }(P<0.002) \\
\text { Insulin } A \cup \mathrm{C}_{0-120 \mathrm{~min}}: 13 \% \text { decrease with } \\
\text { mycoprotein }(P<0.05)\end{array}$ \\
\hline (28) & 36 & $19 / 17$ & $\begin{array}{l}\text { Mean: } 33(\mathrm{sD} 14) \text { years/ } \\
\text { mean: } 28 \cdot 1(\mathrm{sD} 2 \cdot 3) \mathrm{kg} / \mathrm{m}^{2} / \\
\text { healthy/non-smokers }\end{array}$ & $\begin{array}{l}\text { RCT, single- } \\
\text { blinded, } \\
\text { crossover }\end{array}$ & $\begin{array}{l}\text { Solid/44, } 88 \text { and } 132 \mathrm{~g} \text { wet weight/energy } \\
\text { and macronutrient-matched (except } \\
\text { fibre) chicken }(22,44 \text { and } 66 \mathrm{~g}) / 25- \\
30 \mathrm{~g} \mathrm{CHO}\end{array}$ & $\begin{array}{l}\text { Participant had a standard evening } \\
\text { meal, } 12 \mathrm{~h} \text { overnight fast, asked to } \\
\text { refrain from alcohol and avoid any } \\
\text { strenous exercise } 24 \mathrm{~h} \text { prior to the } \\
\text { study visit } \\
\text { Test meal followed by an ad libitum } \\
\text { meal at } 180 \text { min } \\
\text { Blood sampling at }-15,0,15,30,45 \text {, } \\
\quad 60,90,120,150 \text { and } 180 \mathrm{~min} \\
\text { relative to test food }\end{array}$ & $\begin{array}{l}\text { Glucose iAUC }{ }_{0-180 \text { min: NSSD with } 44,88} \\
\text { and } 132 \mathrm{~g} \text { of mycoprotein } v \text {. matched } \\
\text { controls } \\
\text { Insulin iAUC } \mathrm{A}_{0-180 \mathrm{~min}}: 9 \%(P=0.024) \\
12 \%(P=0.001) \text { and } 21 \%(P<0.001) \\
\text { decrease with } 44,88 \text { and } 132 \mathrm{~g} \text { of } \\
\text { mycoprotein, respectively, } v \text {. matched } \\
\text { controls }\end{array}$ \\
\hline (29) & 12 & $12 / 0$ & $\begin{array}{l}\text { Mean: } 28 \text { (sD 6.92) years/ } \\
\text { mean: } 26(\mathrm{sD} 3.46) \mathrm{kg} / \mathrm{m}^{2} / \\
\text { healthy } / \text { non-smokers }\end{array}$ & $\begin{array}{l}\text { RCT, single- } \\
\text { blinded, } \\
\text { crossover }\end{array}$ & $\begin{array}{l}\text { Drink } / 20 \mathrm{~g} \text { (mass-matched), } 40 \mathrm{~g} \text { (protein- } \\
\text { matched), } 60 \mathrm{~g} \text { and } 80 \mathrm{~g} \text { wet weight } / \text { not } \\
\text { energy or other macronutrient-matched } \\
\text { milk protein }(20 \mathrm{~g}) / \text { protein: } \mathrm{CHO} \text { ratio of } \\
23 \text { (in } 20 \mathrm{~g} \text { of milk) and of } 4.5 \text { (in } 20, \\
40,60 \text { and } 80 \mathrm{~g} \text { of mycoprotein) }\end{array}$ & $\begin{array}{l}\text { Participant fasted. Abstained from } \\
\text { physical activity and alcohol } 48 \mathrm{~h} \\
\text { prior to the study visit. Blood } \\
\text { sampling at }-5,15,30,45,60,90, \\
120,150,180,210 \text { and } 240 \mathrm{~min} \\
\text { relative to test food }\end{array}$ & 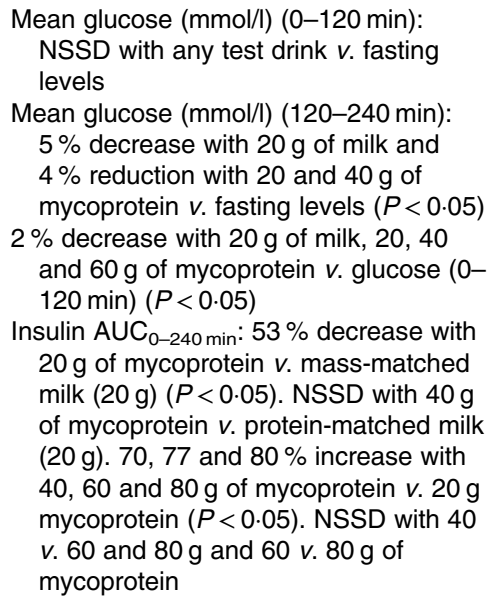 \\
\hline
\end{tabular}

$\mathrm{CHO}$, carbohydrate; RCT, randomised controlled trial; NSSD, no statistically significant difference; iAUC, incremental AUC.

${ }^{*}$ Glucose and insulin AUC are expressed as a percentage change from control food. Age and BMI expressed as mean values and standard deviations. 


\section{N British Journal of Nutrition}

Table 4. Summary of the acute randomised trials on energy intake and appetite*

(Numbers and percentages; mean values and standard deviations)

\begin{tabular}{|c|c|c|c|c|c|c|c|c|c|c|}
\hline \multirow[b]{2}{*}{ References } & \multicolumn{3}{|r|}{ Participants } & \multicolumn{3}{|c|}{ Study information } & \multicolumn{4}{|c|}{ Outcomes } \\
\hline & $n$ & $\begin{array}{l}\text { Male/ } \\
\text { female }\end{array}$ & $\begin{array}{l}\text { Characteristics (age, } \\
\text { BMI, health and smoking } \\
\text { status) }\end{array}$ & Study design & $\begin{array}{l}\text { Test food (form/quantity } \\
\text { of mycoprotein/control } \\
\text { type/CHO) }\end{array}$ & Protocol & $\begin{array}{l}\text { Energy intake } \\
\text { assessment method }\end{array}$ & $\begin{array}{l}\text { Effect on energy } \\
\text { intake }\end{array}$ & $\begin{array}{l}\text { Appetite } \\
\text { assessment } \\
\text { method }\end{array}$ & $\begin{array}{l}\text { Effect on appetite } \\
\text { subjective feelings }\end{array}$ \\
\hline (30) & 13 & $0 / 13$ & $\begin{array}{l}\text { Mean: } 24.8 \text { (sD } \\
7.9) \text { years, mean: } \\
22.25(\mathrm{sD} 2.50) \mathrm{kg} / \mathrm{m}^{2} \\
\text { healthy, one smoker }\end{array}$ & $\begin{array}{l}\mathrm{RCT} \text {, crossover, } \\
\text { not blinded }\end{array}$ & $\begin{array}{l}\text { Solid/130 g wet weight/energy } \\
\text { and macronutrient-matched } \\
\text { (except from fibre) chicken/ } \\
77-80 \mathrm{~g} \mathrm{CHO}\end{array}$ & $\begin{array}{l}\text { Participant fasted from } \\
\text { midnight. No } \\
\text { breakfast } \\
\text { was given } \\
\text { Test food served at } \\
\text { lunchtime }\end{array}$ & $\begin{array}{l}\text { Weighed food diary } \\
\text { using digital food } \\
\text { balances recorded } \\
\text { for } 3 \mathrm{~d} \text { (the day } \\
\text { before, on the day, } \\
\text { day after study visit) }\end{array}$ & $\begin{array}{l}24 \% \text { decrease on the } \\
\text { day }(P<0.01) \text { and } \\
\text { by } 16 \% \text { on the day } \\
\text { after }(P<0.05) \text { with } \\
\text { mycoprotein }\end{array}$ & $\begin{array}{l}\text { VAS }(100 \mathrm{~mm}) \\
\text { right after } \\
\text { the meal } \\
\text { and at } 60, \\
120 \text { and } \\
180 \text { min }\end{array}$ & $\begin{array}{l}\text { Decrease by } 25 \% \text { in } \\
\text { the desire to eat at } \\
180 \text { min }(P<0.05) \\
\text { and by } 39 \% \text { in } \\
\text { prospective } \\
\text { consumption } \\
\text { feeling at } 180 \text { min } \\
(P<0.01) \text { with } \\
\text { mycoprotein } \\
\text { NSSD in hunger or } \\
\text { fullness feelings } \\
\text { with mycoprotein }\end{array}$ \\
\hline (31) & 42 & $0 / 42$ & $\begin{array}{l}\text { Mean: } 30.14 \\
\text { (sD } 9.59) \text { years, mean: } \\
27.42(\mathrm{sD} 1.62) \mathrm{kg} / \mathrm{m}^{2} \\
\text { healthy, non-smokers }\end{array}$ & $\mathrm{RCT}$, crossover† & $\begin{array}{l}\text { Solid/44.3 g wet weight/energy } \\
\text { and macronutrient-matched } \\
\text { chicken (except fibre) and tofu/ } \\
63.6-65.3 \mathrm{~g} \mathrm{CHO}\end{array}$ & $\begin{array}{l}\text { Participant fasted } \\
\text { overnight } \\
\text { for } 12 \mathrm{~h} \text { and deprived } \\
\text { of exercise and } \\
\text { alcohol } 24 \mathrm{~h} \text { prior to } \\
\text { the study visit } \\
\text { Standard breakfast } \\
\text { served in the study } \\
\text { visit. } 4 \mathrm{~h} \text { later a } 220 \mathrm{~g} \\
\text { pasta meal with test } \\
\text { food is served } \\
\text { At } 20 \text { min later, an ad } \\
\text { libitum meal of } \\
\text { sandwiches is } \\
\text { served and asked to } \\
\text { consume as much } \\
\text { as wished. } 4.5 \mathrm{~h} \\
\text { later, an ad libitum } \\
\text { dinner is served } \\
\text { using MSSP }\end{array}$ & $\begin{array}{l}\text { Ad libitum meal at } \\
\text { dinner ( } 4.5 \mathrm{~h} \text { post- } \\
\text { test food ingestion) } \\
\text { using MSSP }\end{array}$ & $\begin{array}{l}12 \% \text { decreased intake } \\
\text { of total grams of } \\
\text { food, energy and all } \\
\text { macronutrient at ad } \\
\text { libitum, } v \text {. chicken, } \\
(P<0.05) \text {, and } \\
\text { similarly to tofu } \\
\text { Mycoprotein did not } \\
\text { affect the duration } \\
\text { of food intake } \\
\text { NSSD in energy } \\
\text { intake with } \\
\text { mycoprotein, } \\
\text { chicken or tofu } \\
(P=0.33) \\
18 \%(+427 \mathrm{~kJ}) \\
\text { increase in high fat/ } \\
\text { high sugar foods } \\
\text { with mycoprotein } v . . \\
\text { tofu }(P<0.01), \text { and } \\
\text { similarly to chicken } \\
(-84 \mathrm{~kJ})(P<0.01)\end{array}$ & $\begin{array}{l}\text { VAS }(100 \mathrm{~mm}) \\
\text { before and } \\
\text { after the } \\
\text { three meals } \\
\text { and at } 30, \\
60,90,120, \\
180 \text { and } \\
240 \text { min } \\
\text { after lunch }\end{array}$ & $\begin{array}{l}\text { SSD in time effect. } \\
\text { NSSD in treatment } \\
\text { effect. SSD in } \\
\text { interaction time } \times \\
\text { treatment for } \\
\text { hunger } \\
\text { NSSD for subjective } \\
\text { appetite AUC }\end{array}$ \\
\hline
\end{tabular}




\section{N British Journal of Nutrition}

Table 4. (Continued)

\begin{tabular}{|c|c|c|c|c|c|c|c|c|c|c|}
\hline \multirow[b]{2}{*}{ References } & \multicolumn{3}{|r|}{ Participants } & \multicolumn{3}{|c|}{ Study information } & \multicolumn{4}{|c|}{ Outcomes } \\
\hline & $n$ & $\begin{array}{c}\text { Male/ } \\
\text { female }\end{array}$ & $\begin{array}{l}\text { Characteristics (age, } \\
\text { BMI, health and smoking } \\
\text { status) }\end{array}$ & Study design & $\begin{array}{l}\text { Test food (form/quantity } \\
\text { of mycoprotein/control } \\
\text { type/CHO) }\end{array}$ & Protocol & $\begin{array}{l}\text { Energy intake } \\
\text { assessment method }\end{array}$ & $\begin{array}{l}\text { Effect on energy } \\
\text { intake }\end{array}$ & $\begin{array}{l}\text { Appetite } \\
\text { assessment } \\
\text { method }\end{array}$ & $\begin{array}{l}\text { Effect on appetite } \\
\text { subjective feelings }\end{array}$ \\
\hline (28) & 36 & $19 / 17$ & $\begin{array}{l}\text { Mean: } 33 \text { (SD 14) years, } \\
\text { mean: } 28 \cdot 1 \text { (SD } \\
2 \cdot 3) \mathrm{kg} / \mathrm{m}^{2}, \text { healthy, } \\
\text { non-smokers }\end{array}$ & $\begin{array}{l}\mathrm{RCT}, \text { single- } \\
\text { blinded, } \\
\text { crossover }\end{array}$ & $\begin{array}{l}\text { Solid/44, } 88,132 \mathrm{~g} \text { wet weight/ } \\
\text { energy and macronutrient- } \\
\text { matched (except fibre) } \\
\text { chicken }(22,44 \text { and } 66 \mathrm{~g}) / 25- \\
30 \mathrm{~g} \mathrm{CHO}\end{array}$ & $\begin{array}{l}\text { Participant had a } \\
\text { standard evening } \\
\text { meal, } 12 \mathrm{~h} \text { overnight } \\
\text { fast, asked to refrain } \\
\text { from alcohol and } \\
\text { avoid any strenuous } \\
\text { exercise } 24 \mathrm{~h} \text { prior to } \\
\text { the study visit } \\
\text { Test food followed by } \\
\text { an ad libitum meal at } \\
180 \text { min }\end{array}$ & $\begin{array}{l}\text { 3-d food diary (results } \\
\text { reported for energy } \\
\text { intake over } 24 \mathrm{~h} \\
\text { overall) }\end{array}$ & $\begin{array}{l}8 \%(-201 \mathrm{~kJ}) \\
\text { decrease in energy } \\
\text { intake with } 132 \mathrm{~g} \text { of } \\
\text { mycoprotein } \mathrm{v} . \\
\text { matched chicken } \\
(P \leq 0.01) . \mathrm{NSSD} \\
\text { with } 44 \text { or } 88 \mathrm{~g} \text { of } \\
\text { mycoprotein } \mathrm{v} . \\
\text { matched chicken } \\
13 \%(-1042 \mathrm{~kJ}) \\
\text { decrease in energy } \\
\text { intake with } 44 \mathrm{~g} \\
(P=0.047) \text { and } \\
132 \mathrm{~g}(\text { almost } \mathrm{SSD}, \\
P=0.083) . \\
\mathrm{NSSD} \text { with } 88 \mathrm{~g} \text { of } \\
\text { mycoprotein }\end{array}$ & $\begin{array}{l}\text { VAS }(100 \mathrm{~mm}) \\
\text { at }-15,0, \\
15,30,45, \\
60,90,120, \\
150 \text { and } \\
180 \text { min } \\
\text { relative to } \\
\text { test food }\end{array}$ & $\begin{array}{l}22 \% \text { increase in } \\
\text { fullness score at } \\
150 \text { and } 180 \mathrm{~min} \\
\text { with } 132 \mathrm{~g} \text { of } \\
\text { mycoprotein } \\
(P \leq 0.05) \text {. NSSD } \\
\text { in fullness with } 44 \\
\text { and } 88 \mathrm{~g} \text { of } \\
\text { mycoprotein } \\
\text { NSSD in hunger, } \\
\text { desire to eat and } \\
\text { prospective food } \\
\text { intake scores with } \\
44,88 \text { and } 132 \mathrm{~g} \text { of } \\
\text { mycoprotein }\end{array}$ \\
\hline (29) & 12 & $12 / 0$ & $\begin{array}{l}\text { Mean: } 28 \text { (sD } \\
6.92) \text { years, mean: } 26 \\
\text { (sD 3.46) kg/m², } \\
\text { healthy, non-smokers }\end{array}$ & $\begin{array}{l}\text { RCT, single- } \\
\text { blinded, } \\
\text { crossover }\end{array}$ & $\begin{array}{l}\text { Drink/20 g (mass-matched), } \\
40 \mathrm{~g} \text { (protein-matched), } 60 \mathrm{~g} \\
\text { and } 80 \mathrm{~g} \text { wet weight/not } \\
\text { energy or other } \\
\text { macronutrient-matched milk } \\
\text { protein }(20 \mathrm{~g}) / \mathrm{protein}: \mathrm{CHO} \\
\text { ratio of } 23 \text { (in } 20 \mathrm{~g} \text { of milk) } \\
\text { and of } 4.5 \text { (in } 20,40,60 \text { and } \\
80 \mathrm{~g} \text { of mycoprotein) }\end{array}$ & $\begin{array}{l}\text { Participant fasted. } \\
\text { Abstained from } \\
\text { physical activity and } \\
\text { alcohol } 48 \mathrm{~h} \text { prior to } \\
\text { the study visit } \\
\text { Test food served }\end{array}$ & $\mathrm{N} / \mathrm{A}$ & $\mathrm{N} / \mathrm{A}$ & $\begin{array}{l}\text { VAS }(100 \mathrm{~mm}) \\
\text { at }-15,30, \\
60,90,120, \\
150,180 \\
210 \text { and } \\
240 \text { min } \\
\text { relative to } \\
\text { test food }\end{array}$ & $\begin{array}{l}\text { From } 0 \text { to } 120 \mathrm{~min}, \\
\text { decrease of } \\
\text { appetite with } 20 \mathrm{~g} \\
\text { of milk and } 20,40, \\
60 \text { and } 80 \mathrm{~g} \text { of } \\
\text { mycoprotein } \\
(P<0.05) \\
\text { compared with } \\
\text { baseline levels } \\
\text { From } 120 \text { to } 240 \mathrm{~min}, \\
\text { increase of } \\
\text { appetite with } 20 \mathrm{~g} \\
\text { of milk, } 20,40 \text { and } \\
60 \mathrm{~g} \text { of mycopotein } \\
(P<0.05) \\
\text { compared with } \\
\text { baseline levels } \\
\text { NSSD in appetite with } \\
80 \mathrm{~g} \text { of } \\
\text { mycoprotein } \\
\text { compared with } \\
\text { baseline from } 120 \\
\text { to } 240 \text { min } \\
\text { Statistical analysis } \\
\text { against milk protein } \\
\text { and other doses of } \\
\text { mycoprotein N/A }\end{array}$ \\
\hline
\end{tabular}

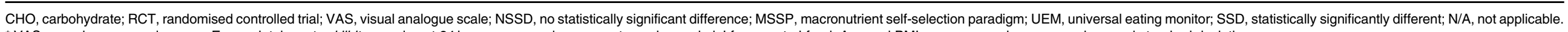
*VAS score is expressed as $\mathrm{mm}$. Energy intakes at ad libitum and post-24 $\mathrm{h}$ are expressed as percentage change in $\mathrm{kJ}$ from control food. Age and BMI are expressed as mean values and standard deviations.

$\dagger$ In Williamson et al.(31), blinding is not mentioned, although authors report that meals were prepared to be as equal as possible in palatability and appearance. 
handbook for systematic review of interventions ${ }^{(32)}$. Results were synthesised according to outcome measure.

\section{Results}

\section{Overview of studies identified}

The conducted search strategy yielded a total of twenty-three potentially relevant articles. Of which, eleven duplicates were identified and removed. Of the remaining twelve potentially relevant articles, six were excluded post-abstract screening as they were a review ( $n 1$ ), European Food Safety Authority report $(n 1)$, conference paper ( $n 2)$, an in vitro study ( $n 1)$ and irrelevant outcome measure $(n 1)$. A total of six potentially relevant full-text articles were therefore assessed for eligibility, during which one was excluded for not meeting the defined inclusion and exclusion criteria: not being an RCT ( $n 1)$. A total of five articles were deemed eligible for inclusion and therefore included in the final synthesis (see Fig. 2). All of these studies were of an acute nature (measurements were performed for a minimum of $180 \mathrm{~min}$ to a maximum of $72 \mathrm{~h}$ post-mycoprotein ingestion).

\section{Risk of bias}

Individual studies were judged as having a high, low or unclear risk of bias for the five methodological features measured (see online Supplementary Table S3).
For studies assessing glycaemic control, for the methodological features of random sequence generation (selection bias), the majority of the studies (66\%) were judged as having an unclear risk of bias, whereas the remaining $33 \%$ was given a low risk of bias. For the allocation concealment (selection bias), all studies (100\%) had an unclear risk of bias. For the method of blinding (performance bias), $100 \%$ of the studies had a low risk of bias. For the blinding of the outcome assessment (detection bias), $100 \%$ of the studies had an unclear risk of bias. For the attrition bias, all studies (100\%) had a high risk of bias. Selective reporting bias was unclear for all studies (100\%).

For studies assessing energy intake, all studies (100\%) were judged as having an unclear risk for both selection bias (random sequence generation and allocation concealment), a low (33\%), high (33\%) and unclear (33\%) risk was given for both performance bias and detection bias, a high risk was given for attrition bias to all studies (100\%) and an unclear risk for selective reporting bias was given for all studies (100\%).

For studies assessing both outcomes (glycaemic control and energy intake), in the methodological features for selection bias (random sequence generation), half of the studies (50\%) were judged as having a low and unclear risk of bias. For the selection bias (allocation concealment), all studies (100\%) had an unclear risk of bias. For the performance bias, all of the studies (100\%) had a low risk of bias. For the detection bias, $100 \%$ of the studies had an unclear risk of bias. For the attrition bias, all studies

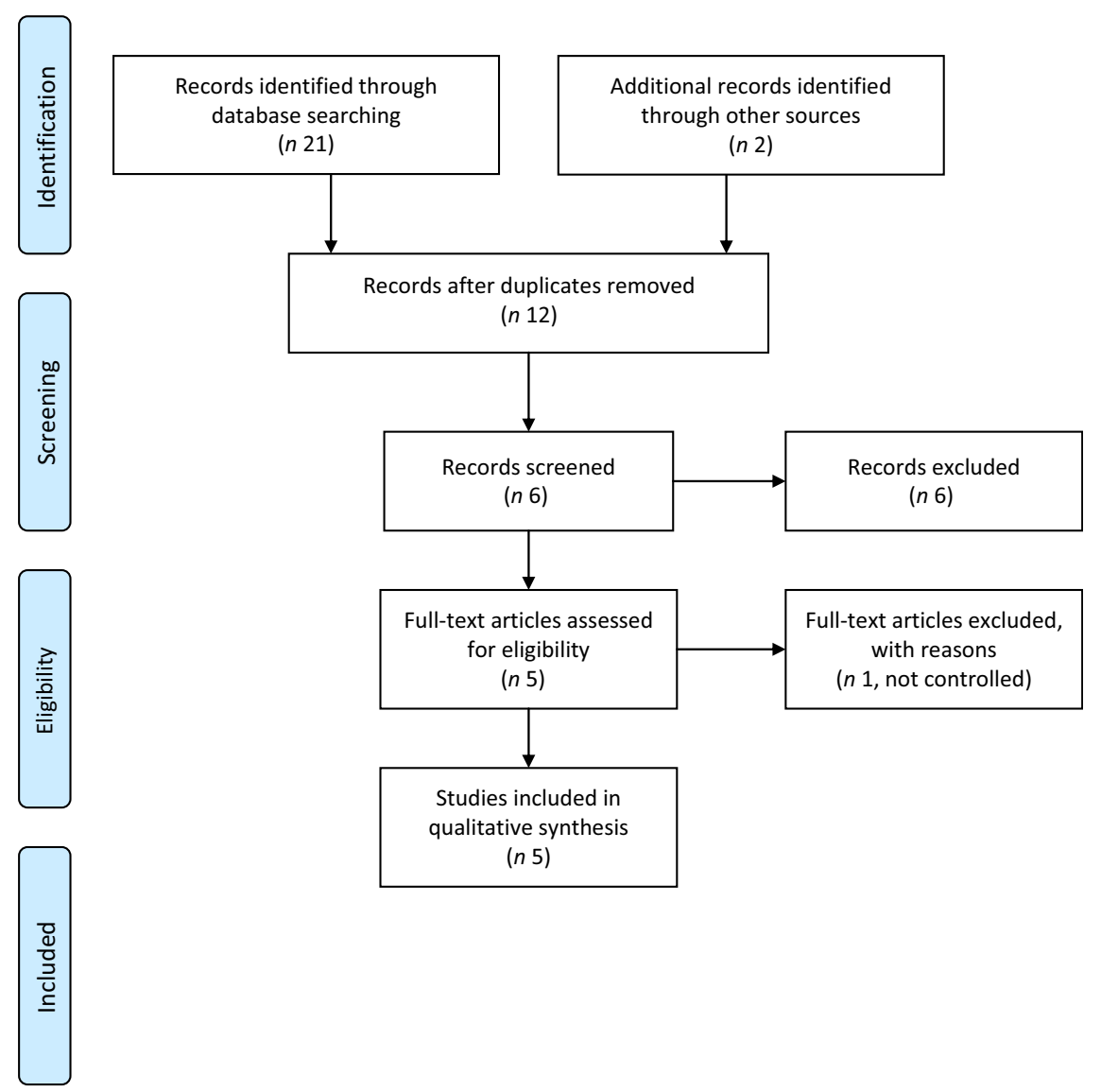

Fig. 2. Preferred Reporting Items for Systematic Reviews and Meta-analysis flow diagram of the literature search and screening process. 
(100\%) were given a high risk of bias. Selective reporting bias was unclear for all studies (100\%).

\section{Studies on glycaemic control}

Table 3 shows the effect of mycoprotein on glycaemic control. In total, three randomised controlled and crossover trials assessed glycaemic control. Two studies ${ }^{(28,29)}$ were conducted in healthy (no chronic disease such as type 2 diabetes), overweight (BMI $\left.25-29.9 \mathrm{~kg} / \mathrm{m}^{2}\right)$ and obese $\left(\mathrm{BMI} \geq 30 \mathrm{~kg} / \mathrm{m}^{2}\right)$ adults and one study $^{(27)}$ with healthy lean (BMI $18.5-24.9 \mathrm{~kg} / \mathrm{m}^{2}$ ) adults. Two studies were conducted using mycoprotein as $\operatorname{liquid}^{(27,29)}$, whereas one used mycoprotein as solid ${ }^{(28)}$. The amounts of mycoprotein ranged from 20 to $132 \mathrm{~g}$. The controls used were chicken $^{(28)}$, soya-based protein ${ }^{(27)}$ and milk protein ${ }^{(29)}$ drink. All three studies assessed insulin AUC and two studies assessed glucose $\mathrm{AUC}^{(27,28)}$. One study assessed mean glucose levels at fasting, early (0-2 h) and late (2-4 h) postprandial state ${ }^{(29)}$

\section{Studies on energy intake and appetite}

Table 4 shows the effect of mycoprotein on energy intake and appetite. In total, four randomised controlled and crossover trials assessed energy intake and appetite. All studies were conducted in healthy humans of which three studies ${ }^{(28,29,31)}$ included adults with a BMI $\geq 25 \mathrm{~kg} / \mathrm{m}^{2}$ and one study ${ }^{(30)}$ with a $\mathrm{BMI}<25 \mathrm{~kg} / \mathrm{m}^{2}$. Three studies were conducted using solid mycoprotein $(28,30,31)$ and one as liquid ${ }^{(29)}$. The amounts used ranged from 44 to $132 \mathrm{~g}$ of mycoprotein. The controls used were chicken in two studies $^{(28,30)}$, milk protein in one study ${ }^{(29)}$ and both chicken and tofu in one study ${ }^{(31)}$. Two studies ${ }^{(28,31)}$ measured acute energy intake ( $<5 \mathrm{~h}$ post-ingestion) via ad libitum intake, of which one study used universal eating monitor and macronutrient self-selection paradigm ${ }^{(31)}$ and one study using a buffet meal $^{(28)}$. Two studies measured energy intake post- $24 \mathrm{~h}$ using 3 -d food diaries ${ }^{(28,30)}$. All four studies explored appetite feelings using subjective appetite scoring via visual analogue scale rating some of the following items: appetite, fullness, prospective food intake, hunger and desire to eat ${ }^{(28-31)}$. All studies assessed feelings of nausea and eating behaviour questionnaires were completed by participants in three studies ${ }^{(28,30,31)}$.

\section{Discussion}

Low intake of total dietary fibre increases the relative risk of developing non-communicable diseases such as type 2 diabetes $^{(33)}$, and high intake of animal-derived protein is also associated with type 2 diabetes risk ${ }^{(34)}$. Therefore, strategies to increase dietary fibre and reduce animal-derived protein are of growing interest. Mycoprotein constitutes a food rich in both dietary fibre and non-animal-derived protein which is being increasingly consumed in the diet of many cultures; however, its effects on blood glucose levels and energy intake have not yet been fully established. This is the first systematic review of RCT investigating the effects of mycoprotein on glycaemia, insulinaemia and energy intake in humans. Overall, five RCT evaluating the effects of mycoprotein on glycaemia, energy intake/appetite or both were identified.

\section{Effect of mycoprotein on glycaemic control}

Three studies reported the effects of mycoprotein on glycaemia and insulinaemia (Table 3), of which one was performed in healthy lean adults ${ }^{(27)}$ and two in healthy overweight and obese $^{(28,29)}$.

\section{Glycaemia}

Blood glucose AUC following the intake of a $20 \mathrm{~g}$ mycoprotein drink showed a reduction in the first $60 \mathrm{~min}$ but not overall $\left(\mathrm{AUC}_{0-120 \mathrm{~min}}\right)$ in healthy lean adults, compared with energy and macronutrient-matched soya-based protein drink ${ }^{(27)}$. A similar experiment in healthy overweight and obese adults showed no differences in blood glucose incremental $\mathrm{AUC}_{0-180}$ following the intake of mycoprotein meal at any dose (44, 88 and $132 \mathrm{~g}$ ) compared with an energy and macronutrient-matched chicken meal ${ }^{(28)}$. These similar effects on blood glucose are interesting as both studies are conducted in different populations (lean $v$. overweight and obese) with varying doses of mycoprotein. When different doses of mycoprotein drink are compared over time, mean glucose levels over the first interval (0-120 min) are unchanged relative to baseline levels but are decreased in the second interval (120-240 min) relative to the first interval (0-120 min) with 20, 40 and $60 \mathrm{~g}$ of mycoprotein. However, this decrease during the second interval (relative to both baseline and the first interval) is also observed following the ingestion of $20 \mathrm{~g}$ of milk protein drink ${ }^{(29)}$.

\section{Insulinaemia}

Insulin AUC was decreased with a drink containing $20 \mathrm{~g}$ of mycoprotein at the first $60 \mathrm{~min}$ but not overall $\left(\mathrm{AUC}_{0-120 \mathrm{~min}}\right)$ in healthy lean individuals compared with a soya-based protein $\operatorname{drink}^{(27)}$. A similar effect in insulin incremental $\mathrm{AUC}_{0-180}$ was shown in overweight and obese individuals when 44, 88 and $132 \mathrm{~g}$ of mycoprotein were compared with an energy and macronutrient-matched chicken $^{(28)}$. These findings, coupled with the observations on blood glucose, suggest that mycoprotein may increase peripheral insulin sensitivity. This is supported by the work of Bottin and colleagues who reported an increased Matsuda index (a measure of insulin sensitivity with higher values indicating improved sensitivity) and reduced insulinogenic index (a measure of insulin output with lower values indicating reduced output) of mycoprotein compared with intake of energy and macronutrient-matched chicken ${ }^{(28)}$. This study is of particular importance as it was performed in overweight and obese individuals, a population that is at greater risk of developing non-communicable diseases in which hyperglycaemia and hyperinsulinaemia are implicated, such as type 2 diabetes ${ }^{(35)}$ and CVD ${ }^{(36)}$.

The effect of increasing doses (20, 40, 60 and $80 \mathrm{~g}$ ) of mycoprotein on insulin $\mathrm{AUC}_{0-240}$ was compared with a milk protein drink, in which $40 \mathrm{~g}$ of mycoprotein drink (containing $18 \mathrm{~g}$ of protein) induced a similar insulin $\mathrm{AUC}_{0-240}$ response to $20 \mathrm{~g}$ of the milk protein drink (containing $16 \mathrm{~g}$ of protein), suggesting that these protein sources produce similar effects on insulinaemia when matched for protein content. Doses of 40, 60 and $80 \mathrm{~g}$ of mycoprotein increased insulin $\mathrm{AUC}_{0-240}$ in a dose-dependent manner, in which these three doses were 
significantly different from $20 \mathrm{~g}$ of mycoprotein. This response is expected as the insulinotropic effect of dietary protein is proportional to the dose ${ }^{(37)}$.

In summary, the effects of mycoprotein on glycaemia are unclear. However, the data suggest that the acute intake of mycoprotein may decrease insulin output in healthy lean and overweight adults. Such conclusions, however, are limited, given they are drawn from a limited number ( $n 3$ ) of highly heterogeneous acute studies. Further understanding and validation of the acute effects of mycoprotein on glycaemia coupled with translation into real-world settings via well-controlled studies investigating chronic effects are required.

\section{Possible mechanisms underlying the effect of mycoprotein on glycaemic control}

The mechanisms involved in the effects of mycoprotein on glycaemia and insulinaemia may be due to a combination of different factors, acting independently or in a concerted manner.

A delay in gastric emptying is often attributed to the reduction in blood glucose observed following protein ${ }^{(17)}$ and fibre ${ }^{(38)}$ ingestion. Nevertheless, $132 \mathrm{~g}$ of mycoprotein showed no effect on gastric emptying compared with energy and macronutrient-matched chicken $^{(28)}$. It should, however, be noted that the methodology (paracetamol) employed in this study to measure gastric emptying when solid foods are consumed is not considered suitable. This is because paracetamol follows a liquid-phase gastric emptying ${ }^{(39)}$, and liquid and solid phases empty at different rates and in patterns $^{(40)}$; therefore, a better methodology should be employed to measure gastric emptying in solid mycoprotein. Thus, an effect of mycoprotein on gastric emptying cannot yet be ruled out.

It is possible that characteristics inherent to mycoprotein (e.g. hyphae, protein and fibre composition) modify the rate of gastric emptying. It has been hypothesised that mycoprotein could delay gastric emptying via the conversion of chitin to its soluble form (namely chitosan) via alkaline deacetylation, although this remains speculative as this process has only been demonstrated in vitro ${ }^{(41)}$. Other mechanisms, such as the secretion of GLP-1 and PYY (two hormones that are involved in gastric emptying via activation of the ileal brake), are also possible. However, Bottin et al. showed no significant differences in neither GLP1 nor PYY following $132 \mathrm{~g}$ of acute mycoprotein relative to energy and macronutrient-matched chicken ${ }^{(28)}$.

Lastly, the protein characteristics of mycoprotein may be responsible - at least in part - for its effect on postprandial insulin concentrations. Mycoprotein possesses a lower insulinotropic amino acid profile as well as a lower 120-min postprandial amino acid appearance relative to protein-matched milk ${ }^{(29)}$ and therefore may explain the reduction in insulin output reported in the literature ${ }^{(27,28)}$.

In summary, the mechanisms underpinning the blood glucose and insulin response of mycoprotein intake are largely unclear. Mechanisms such as altered gastric emptying and the secretion of gastrointestinal hormones warrant further investigation.

\section{Effect of mycoprotein on energy intake}

Four studies have reported the acute effects of mycoprotein on energy intake (Table 4) in healthy lean, overweight and obese humans, with two studies observing a decrease in energy intake at an ad libitum meal ${ }^{(28,31)}$, two in post-24 h energy intake ${ }^{(28,30)}$ and one in energy intake during the day ${ }^{(30)}$. All studies assessed participant's eating behaviour at screening to exclude abnormal responses.

\section{Acute energy intake}

Acute energy intake ( $\leq 5 \mathrm{~h}$ post-ingestion) at a single ad libitum meal was measured in healthy overweight and obese individuals following mycoprotein ingestion and consistently showed an overall reduction relative to energy and macronutrient-matched protein sources.

In healthy overweight and obese individuals, a reduction of ad libitum energy intake by $12 \%(167 \mathrm{~kJ})$ was achieved $20 \mathrm{~min}$ following $44.3 \mathrm{~g}$ of mycoprotein ingestion compared with energy and macronutrient-matched chicken, and similarly to energy and macronutrient-matched tofu ${ }^{(31)}$. In this study, a second ad libitum meal served $4.5 \mathrm{~h}$ post-ingestion showed no differences in energy intake with mycoprotein compared with energy and macronutrient-matched chicken and tofu. This suggests that intake of mycoprotein did not induce a compensatory response in energy intake at $4.5 \mathrm{~h}$ despite a reduced ingestion post-20 min. Interestingly, food intake using the macronutrient self-selection paradigm showed that mycoprotein promoted an increased intake of high fat/high sugar foods compared with energy and macronutrient-matched tofu ${ }^{(31)}$. The magnitude of this effect was however not reported by the authors, and therefore, the potential implications of this finding are difficult to evaluate.

In a more recent study with overweight and obese individuals $^{(28)}$, Bottin et al. tested the effect of 44 and $88 \mathrm{~g}$ of mycoprotein on energy intake at an ad libitum meal $180 \mathrm{~min}$ post-ingestion relative to energy and macronutrient-matched chicken, reporting no differences between protein sources. However, when $132 \mathrm{~g}$ of mycoprotein was tested, an $8 \%$ (201 kJ) reduction in ad libitum energy intake was observed when compared with energy and macronutrient-matched chicken.

The differences in the ad libitum energy intake reduction observed between the two studies could be related to differences in the mycoprotein dose and inter-meal interval employed (i.e. the time between protein ingestion and presentation of the ad libitum meal). However, the small number of studies and the heterogeneous methods employed prevents any definitive conclusions from being made.

\section{Short-term energy intake}

Short-term ( $>5 \mathrm{~h}$ post-ingestion) energy intake was assessed in both healthy lean ${ }^{(30)}$, overweight and obese population ${ }^{(28)}$, showing an overall decrease in energy intake relative to other energy and macronutrient-matched protein sources. In healthy lean individuals, $130 \mathrm{~g}$ of mycoprotein reduced energy intake by $24 \%(987 \mathrm{~kJ})$ on the day and by $16 \%(1180 \mathrm{~kJ})$ on the next day, relative to energy and macronutrient-matched chicken ${ }^{(30)}$. This suggests that mycoprotein did not only induce a compensatory eating response on the day after but also decreased energy intake during the time measured $(2 \mathrm{~d})$. Foods rich in dietary fibre and/or protein have been shown to acutely and 
chronically decrease energy intake $\mathrm{e}^{(11,42-44)}$. Considering the literature on other foods high in fibre and/or protein, and the acute data on mycoprotein, we could hypothesise that chronic intake of mycoprotein results in a net reduction in energy intake, although this remains to be investigated.

In a separate study, healthy overweight and obese people showed a smaller decrease in energy intake (13\%; $1042 \mathrm{~kJ})$ on the next day following $44 \mathrm{~g}$ of mycoprotein compared with energy and protein-matched chicken, even though 88 and $132 \mathrm{~g}$ of mycoprotein did not significantly decrease energy intake ${ }^{(28)}$. This difference in energy intake is possibly due to the heterogeneity of the studies (i.e. different BMI, proportion males/females that could have affected appetite feelings due to menses) or due to the reporting method used in one study ${ }^{(28)}$ using self-reported food diaries $(v$. weighted food diaries using digital scales) whose validity has been questioned $^{(45)}$.

In summary, the limited data suggest that acute mycoprotein may reduce energy intake at an ad libitum meal and over the short-term ( $>5 \mathrm{~h}$ post-ingestion) in healthy lean, overweight and obese individuals. Such conclusions, however, are limited, given they are drawn from a limited number $(n 4)$ of highly heterogeneous acute studies. Further understanding and validation of the acute effects of mycoprotein on energy intake coupled with translation into real-world settings via well-controlled studies investigating the chronic effects are required.

\section{Possible mechanisms underlying the effect of mycoprotein on energy intake}

Different mechanisms, acting separately or together, may have been involved in the effect of mycoprotein on energy intake.

Subjective appetite has been demonstrated to correlate with subsequent energy intake ${ }^{(46)}$. Mycoprotein showed a decrease in energy intake at an ad libitum meal following a decrease in subjective appetite ${ }^{(28,29)}$. Furthermore, this reduction in subjective appetite and energy intake may be mediated by changes in gastrointestinal hormones related to satiety. Despite mycoprotein showing no differences in GLP-1 and PYY concentrations compared with energy and macronutrient-matched chicken ${ }^{(28)}$, the role of other appetite-regulating gut hormones (e.g. cholecystokinin or ghrelin) has not been investigated. Metabolomics analysis also indicates that mycoprotein intake increases the presence of guanidine acetic acid and $\beta$-hydroxybutyrate, which are known to suppress appetite via direct interaction with the hypothalamus ${ }^{(28,47-49)}$. Additionally, while a reduction in gastric emptying and/or transit time correlates with appetite ${ }^{(14)}$, the effect of mycoprotein on gastric emptying is unclear. At present, only one study has measured gastric emptying following mycoprotein ingestion, showing no effect compared with energy and macronutrient-matched chicken ${ }^{(28)}$. However, as previously mentioned, the paracetamol method is not an appropriate method to measure gastric emptying in solid foods. In support of this, the presence of insoluble fibre within mycoprotein (of which certain types can increase gut transit time ${ }^{(50)}$ ), as well as data showing a steady plasma amino acid appearance following mycoprotein intake ${ }^{(29)}$ (compared with an acute appearance with protein-matched milk protein), suggests that mycoprotein may decrease the rate of gastric emptying.
The effects of mycoprotein on short-term ( $>5 \mathrm{~h}$ post-ingestion) energy reduction could be in part due to fibre fermentation by the resident gut microbiota and the subsequent production of the SCFA acetate, butyrate and propionate. A recent study using in vitro batch culture fermentation with human faeces showed that mycoprotein fibre increased the production of propionate, without affecting acetate or butyrate levels ${ }^{(51)}$. Propionate has been shown to increase GLP-1 and PYY production and to decrease acute energy intake in overweight humans ${ }^{(52)}$. Therefore, it is plausible that the intake of mycoprotein in humans may have stimulated similar pathways to induce positive effects on appetite and ultimately energy intake.

Although these are all conceivable possibilities, the evidence is limited and hence further research is needed to uncover the mechanisms relating to mycoprotein-induced decreases in subjective appetite, acute and short-term energy intake.

\section{Conclusion}

Mycoprotein is a food high in both dietary fibre and non-animalderived protein whose consumption is increasing across the world. This systematic review reports that the acute effects of mycoprotein on glycaemia are currently unclear, but likely decrease insulinaemia and energy intake (at an ad libitum meal and post-24h) in healthy lean and overweight and obese humans acutely. The mechanisms underpinning these effects are not yet elucidated and should be further explored. In addition to clarifying the acute effects of mycoprotein on glycaemia, the translation of these findings into real-world settings via wellcontrolled chronic investigations is a logical next step.

\section{Acknowledgements}

The Section for Nutrition Research, Department of Metabolism, Digestion and Reproduction is funded by grants from the MRC, BBSRC, NIHR, an Integrative Mammalian Biology (IMB) Capacity Building Award, an FP7- HEALTH- 2009- 241592 EuroCHIP grant and is supported by the NIHR Biomedical Research Centre Funding Scheme. The views expressed are those of the author(s) and not necessarily those of the NHS, the NIHR or the Department of Health. This work was supported by an educational no string grant from Marlow Foods Ltd, Stokesley, UK. The funder did not contribute to the manuscript of this paper.

The authors' contributions were as follows: All authors (A. C.-M., A. M. L., J. F., E. S. C., T. J. A. F. and G. S. F.) wrote the introduction; A. C.-M., G. S. F. and A. M. L. designed the research; A. C.-M., A. M. L. and E. S. C. did the screening; A. C.-M. did the data extraction; A. C.-M., A. M. L., J. F. and E. S. C. did the interpretation of findings and discussion. A. C.-M. has primary responsibility for final content. All authors read and approved the final manuscript.

A. C.-M. is funded by Marlow Foods Ltd. G. S. F. is currently giving and has given consultant advice to Marlow Foods Ltd. T. J. A. F. works for Marlow Foods Ltd. A. M. L., J. F. and E. S. C. have no conflicts of interest. Marlow Foods Ltd was not involved in the screening, data extraction, interpretation and discussion. 


\section{Supplementary material}

For supplementary material referred to in this article, please visit https://doi.org/10.1017/S0007114520000756

\section{References}

1. World Health Organization (2018) Noncommunicable Diseases Country Profiles 2018. WHO Global Report. Geneva: WHO.

2. Lim SS, Vos T, Flaxman AD, et al. (2012) A comparative risk assessment of burden of disease and injury attributable to 67 risk factors and risk factor clusters in 21 regions, 1990-2010: a systematic analysis for the Global Burden of Disease Study 2010. Lancet 380, 2224-2260.

3. World Health Organization (2006) Definition and Diganosis of Diabetes Mellitus and Intermediate Hyperglycaemia: Report of a WHO/IDF Consultation. WHO Global Report. Geneva: WHO.

4. Bray GA (1978) Definition, measurement, and classification of the syndromes of obesity. Int J Obes 2, 99-112.

5. Murea M, Ma L \& Freedman BI (2012) Genetic and environmental factors associated with type 2 diabetes and diabetic vascular complications. Rev Diabet Stud 9, 6.

6. Ajala O, English P \& Pinkney J (2013) Systematic review and meta-analysis of different dietary approaches to the management of type 2 diabetes. Am J Clin Nutr 97, 505-516.

7. Chutkan R, Fahey G, Wright WL, et al. (2012) Viscous versus nonviscous soluble fiber supplements: mechanisms and evidence for fiber-specific health benefits. J Am Assoc Nurse Pract 24, 476-487.

8. Dhital S, Gidley MJ \& Warren FJ (2015) Inhibition of $\alpha$-amylase activity by cellulose: kinetic analysis and nutritional implications. Carbohydr Polym 123, 305-312.

9. Tarini J \& Wolever TM (2010) The fermentable fibre inulin increases postprandial serum short-chain fatty acids and reduces free-fatty acids and ghrelin in healthy subjects. Appl Physiol Nutr Metab 35, 9-16.

10. Wong JM, De Souza R, Kendall CW, et al. (2006) Colonic health: fermentation and short chain fatty acids. J Clin Gastroenterol 40, 235-243.

11. Wanders AJ, van den Borne JJ, de Graaf C, et al. (2011) Effects of dietary fibre on subjective appetite, energy intake and body weight: a systematic review of randomized controlled trials. Obes Rev 12, 724-739.

12. Slavin J \& Green H (2007) Dietary fibre and satiety. Nutr Bull 32, 32-42.

13. De Graaf C, Blom WA, Smeets PA, et al. (2004) Biomarkers of satiation and satiety. Am J Clin Nutr 79, 946-961.

14. Bergmann J, Chassany O, Petit A, et al. (1992) Correlation between echographic gastric emptying and appetite: influence of psyllium. Gut 33, 1042-1043.

15. Byrne C, Chambers E, Morrison D, et al. (2015) The role of short chain fatty acids in appetite regulation and energy homeostasis. Int J Obes 39, 1331.

16. Nuttall FQ, Mooradian AD, Gannon MC, et al. (1984) Effect of protein ingestion on the glucose and insulin response to a standardized oral glucose load. Diabetes Care 7, 465-470.

17. Ma J, Stevens JE, Cukier K, et al. (2009) Effects of a protein preload on gastric emptying, glycemia, and gut hormones after a carbohydrate meal in diet-controlled type 2 diabetes. Diabetes Care 32, 1600-1602.

18. Lindgren $\mathrm{O}$, Pacini $\mathrm{G}$, Tura A, et al. (2015) Incretin effect after oral amino acid ingestion in humans. J Clin Endocrinol Metab 100, 1172-6.
19. Mithieux G, Misery P, Magnan C, et al. (2005) Portal sensing of intestinal gluconeogenesis is a mechanistic link in the diminution of food intake induced by diet protein. Cell Metab 2, 321-329.

20. Rampone A \& Reynolds P (1991) Food intake regulation by diet-induced thermogenesis. Med Hypotheses 34, 7-12.

21. Belza A, Ritz C, Sørensen MQ, et al. (2013) Contribution of gastroenteropancreatic appetite hormones to protein-induced satiety. Am J Clin Nutr 97, 980-989.

22. Finnigan TJA, Needham L \& Abbott CM (2016) Mycoprotein: a healthy new protein with a low environmental impact. In Sustainable Proteins, pp. 301-326 [S Nadathur, JPD Wanasundara and L Scanlin, editors]. Cambridge, MA: Academic Press.

23. Riquelme M, Aguirre J, Bartnicki-García S, et al. (2018) Fungal morphogenesis, from the polarized growth of hyphae to complex reproduction and infection structures. Microbiol Mol Biol Rev 82, e00068-00017.

24. Wiebe M (2002) Myco-protein from Fusarium venenatum: a well-established product for human consumption. Appl Microbiol Biotechnol 58, 421-427.

25. Fesel PH \& Zuccaro A (2016) $\beta$-glucan: crucial component of the fungal cell wall and elusive MAMP in plants. Fungal Genet Biol 90, 53-60.

26. Moher D, Liberati A, Tetzlaff J, et al. (2009) Preferred reporting items for systematic reviews and meta-analyses: the PRISMA statement. Ann Intern Med 151, 264-269.

27. Turnbull WH \& Ward T (1995) Mycoprotein reduces glycemia and insulinemia when taken with an oral-glucose-tolerance test. Am J Clin Nutr 61, 135-140.

28. Bottin JH, Swann JR, Cropp E, et al. (2016) Mycoprotein reduces energy intake and postprandial insulin release without altering glucagon-like peptide- 1 and peptide tyrosine-tyrosine concentrations in healthy overweight and obese adults: a randomisedcontrolled trial. Br J Nutr 116, 360-374

29. Dunlop MV, Kilroe SP, Bowtell JL, et al. (2017) Mycoprotein represents a bioavailable and insulinotropic non-animalderived dietary protein source: a dose-response study. $\mathrm{BrJ}$ Nutr 118, 673-685.

30. Turnbull WH, Walton J \& Leeds AR (1993) Acute effects of mycoprotein on subsequent energy intake and appetite variables. Am J Clin Nutr 58, 507-512.

31. Williamson DA, Geiselman PJ, Lovejoy J, et al. (2006) Effects of consuming mycoprotein, tofu or chicken upon subsequent eating behaviour, hunger and safety. Appetite 46, 41-48.

32. Higgins JP (2008) Cochrane Handbook for Systematic Reviews of Interventions version 5.0. 1. The Cochrane Collaboration. http://www cochrane-handbook org.

33. Reynolds A, Mann J, Cummings J, et al. (2019) Carbohydrate quality and human health: a series of systematic reviews and meta-analyses. Lancet 393, 434-445.

34. Sluijs I, Beulens JW, Spijkerman AM, et al. (2010) Dietary intake of total, animal, and vegetable protein and risk of type 2 diabetes in the European Prospective Investigation into Cancer and Nutrition (EPIC)-NL study. Diabetes Care 33, 43-48.

35. Zheng Y, Ley SH \& Hu FB (2018) Global aetiology and epidemiology of type 2 diabetes mellitus and its complications. Nature Reviews Endocrinology 14, 88.

36. Coutinho M, Gerstein HC, Wang Y, et al. (1999) The relationship between glucose and incident cardiovascular events. A metaregression analysis of published data from 20 studies of 95,783 individuals followed for 12.4 years. Diabetes Care 22, 233-240.

37. Gunnerud U, Östman E \& Björck I (2013) Effects of whey proteins on glycaemia and insulinaemia to an oral glucose 
load in healthy adults; a dose-response study. Eur J Clin Nutr 67, 749 .

38. Jenkins DJ, Jenkins AL (1985) Dietary fiber and the glycemic response. Proc Soc Exp Biol Med 180, 422-431.

39. Wagner JG \& Nelson E (1964) Kinetic analysis of blood levels and urinary excretion in the absorptive phase after single doses of drug. J Pharm Sci 53, 1392-1403.

40. Horowitz M, Collins PJ \& Shearman DJ (1985) Disorders of gastric emptying in humans and the use of radionuclide techniques. Arch Intern Med 145, 1467-1472.

41. Turnbull WH (1998) Myco-protein as a functional food: effects on lipemia, glycemia and appetite variables. 16th International Congress of Nutrition, pp. 249-251.

42. Halton TL \& Hu FB (2004) The effects of high protein diets on thermogenesis, satiety and weight loss: a critical review. J Am Coll Nutr 23, 373-385.

43. Lluch A, Hanet-Geisen N, Salah S, et al. (2010) Short-term appetite-reducing effects of a low-fat dairy product enriched with protein and fibre. Food Qual Preference 21, 402-409.

44. Lee YP, Mori TA, Sipsas S, et al. (2006) Lupin-enriched bread increases satiety and reduces energy intake acutely. $\mathrm{Am} \mathrm{J}$ Clin Nutr 84, 975-980.

45. Wolper C, Heshka S \& Heymsfield SB (1995) Measuring food intake: an overview. In Handbook of Assessment Methods for Eating Behaviors and Weight-related Problems: Measures,
Theory, and Research, pp. 215-240 [DB Allison, editor]. Thousand Oaks, CA: Sage Publications, Inc.

46. Parker BA, Sturm K, MacIntosh C, et al. (2004) Relation between food intake and visual analogue scale ratings of appetite and other sensations in healthy older and young subjects. Eur I Clin Nutr 58, 212.

47. Jordi J, Herzog B, Camargo SM, et al. (2013) Specific amino acids inhibit food intake via the area postrema or vagal afferents. J Physiol 591, 5611-5621.

48. Alamshah A, McGavigan AK, Spreckley E, et al. (2016) L-Arginine promotes gut hormone release and reduces food intake in rodents. Diabetes Obes Metab 18, 508-518.

49. Stubbs BJ, Cox PJ, Evans RD, et al. (2018) A ketone ester drink lowers human ghrelin and appetite. Obesity $\mathbf{2 6}$, 269-273.

50. Burkitt DP, Walker A \& Painter NS (1972) Effect of dietary fibre on stools and transit-times, and its role in the causation of disease. Lancet 300, 1408-1411.

51. Harris HC, Edwards CA \& Morrison DJ (2019) Short chain fatty acid production from mycoprotein and mycoprotein fibre in an in vitro fermentation model. Nutrients $\mathbf{1 1}, 800$.

52. Chambers ES, Viardot A, Psichas A, et al. (2015) Effects of targeted delivery of propionate to the human colon on appetite regulation, body weight maintenance and adiposity in overweight adults. Gut 64, 1744-1754. 